\title{
Monoterpene and sesquiterpene emissions from Quercus coccifera exhibit interacting responses to light and temperature
}

\author{
M. Staudt ${ }^{1}$ and L. Lhoutellier ${ }^{1}{ }^{*}$ \\ ${ }^{1}$ Centre d'Ecologie Fonctionnelle et Evolutive Montpellier, CNRS, 1919 Route de Mende, 34293 Montpellier cedex 5, France \\ *now at: Centre d'IRD, BP 64501, 34394 Montpellier cedex 5, France
}

Received: 13 May 2011 - Published in Biogeosciences Discuss.: 16 June 2011

Revised: 21 September 2011 - Accepted: 22 September 2011 - Published: 28 September 2011

\begin{abstract}
Light and temperature are known to be the most important environmental factors controlling biogenic volatile organic compound (BVOC) emissions from plants, but little is known about their interdependencies especially for BVOCs other than isoprene. We studied light responses at different temperatures and temperature responses at different light levels of foliar BVOC emissions, photosynthesis and chlorophyll fluorescence on Quercus coccifera, an evergreen oak widespread in Mediterranean shrublands. More than $50 \mathrm{BVOCs}$ were detected in the emissions from $Q$. coccifera leaves most of them being isoprenoids plus a few green leaf volatiles (GLVs). Under standard conditions non-oxygenated monoterpenes (MT-hc) accounted for about $90 \%$ of the total BVOC release (mean \pm SD: $738 \pm 378 \mathrm{ng} \mathrm{m}^{-2}$ projected leaf $\operatorname{area~s}^{-1}$ or $13.1 \pm 6.9 \mu \mathrm{gg}^{-1}$ leaf dry weight $\mathrm{h}^{-1}$ ) and oxygenated monoterpenes (MT-ox) and sesquiterpenes (SQTs) accounted for the rest in about equal proportions. Except GLVs, emissions of all BVOCs responded positively to light and temperature. The light responses of MT and SQT emissions resembled that of $\mathrm{CO}_{2}$-assimilation and were little influenced by the assay temperature: at high assay temperature, MT-hc emissions saturated at lower light levels than at standard assay temperature and tended even to decrease in the highest light range. The emission responses to temperature showed mostly Arrhenius-type response curves, whose shapes in the high temperature range were clearly affected by the assay light level and were markedly different between isoprenoid classes: at non-saturating light, all isoprenoids showed a similar temperature optimum $\left(\sim 43^{\circ} \mathrm{C}\right)$, but, at higher temperatures, MT-hc emissions decreased faster than MT-ox and SQT emissions. At saturating light, MT-hc emissions peaked around $37^{\circ} \mathrm{C}$ and rapidly dropped at higher temperatures, whereas MT-ox and SQT emissions strongly
\end{abstract}

Correspondence to: M. Staudt (michael.staudt@cefe.cnrs.fr) increased between 40 and $50^{\circ} \mathrm{C}$ accompanied by a burst of GLVs. In all experiments, decreases of MT-hc emissions under high temperatures were correlated with decreases in $\mathrm{CO}_{2}$-assimilation and/or photosynthetic electron transport. We conclude that light and temperature can have interactive short-term effects on the quantity and quality of BVOC emissions from $Q$. coccifera through substrate limitations of MT biosynthesis occurring at temperatures supraoptimal for photosynthetic processes that are exacerbated by oxidative stress and membrane damages. Such interactive effects are likely to occur frequently during hot and dry summers and simulations made in this work showed that they may have important consequences for emission predictions.

\section{Introduction}

Plants emit a wide range of biogenic volatile organic compounds (BVOCs) to the atmosphere as products of different metabolic pathways (Laothawornkitkul et al., 2009). Volatile isoprenoids i.e. isoprene, methyl-butenol, monoterpenes and sesquiterpenes, are quantitatively the most important and chemically the most diversified group of plant BVOCs. The emission of volatile isoprenoids is estimated to be around ten times higher than emissions from anthropogenic sources (Goldstein and Galbally, 2007). The chemical degradation of BVOCs in the air has significant implications on the buildup and destruction of tropospheric ozone as well as on the formation and growth of secondary aerosols and cloud condensation nuclei. Tropospheric ozone, aerosols and clouds are important components in the earth climate system. Given that man-made global changes in climate, greenhouse gas concentrations and land uses may have deep impacts on the regional and global BVOC budgets, positive and negative feed-backs on global warming are conceivable (Peñuelas and Staudt, 2010).

Published by Copernicus Publications on behalf of the European Geosciences Union. 
Since the 60s, numerous studies have been conducted to quantify BVOC emission rates at leaf, plant and canopy levels and to understand their temporal and spatial variations. Early on, light and temperature were recognized as the most important environmental drivers of isoprenoid emissions. Pioneer studies reported by Rasmussen and Jones (1973), Tyson et al. (1974), Tingey et al. (1979, 1980) and later by Guenther et al. (1991) and other authors (see Laothawornkitkul et al., 2009 and Niinemets et al., 2010 for overview) have shown that emissions respond non-linearly to temperature and light with fundamental differences between monoterpenes (MTs) emitted by conifers and aromatic plants storing BVOC in glandular organs, and isoprene, which is never stored inside plant organs and is emitted by many broad leaf tree species such as oaks, poplars and willows (Kesselmeier and Staudt, 1999): isoprene emission responds to light following a rectangular hyperbola similar to that of photosynthesis, while its response to temperature resembles an Arrhenius function with an exponential increase at low temperatures, a temperature optimum typically lying around $40^{\circ} \mathrm{C}$ and a rapid decline at higher temperatures. By contrast, MT emissions from MT storing species show no clear responses to light variations and increase exponentially with temperature throughout the whole tested temperature ranges. These findings have been used to develop leaf emission models and up-scaling procedures that estimate regional and global budgets of BVOC fluxes. The most frequently used modeling approach is that proposed by Guenther et al. (1993) due to its robustness and simplicity. This approach relies on the hypothesis that emissions of stored isoprenoids mainly result from diffusion processes out of storage organs independent of physiological processes, whereas the emissions of non-stored isoprenoids are essentially controlled by the rate of biosynthesis, where the light response would reflect the dependence of biosynthesis to primary substrates coming predominantly from photosynthetic processes, and the temperature response the activity of rate-limiting enzymes, such as the isoprene synthase within the BVOC biosynthesis pathway.

Since then, light and temperature responses of BVOC emissions have been measured on at least 60 different plant species (Peñuelas and Staudt, 2010) and many other studies have been conducted to gain more insight into the controls over emissions (see reviews by Loreto and Schnitzler, 2010; Monson et al., 2007; Schnitzler et al., 2010; Sharkey et al., 2008). Despite this, our understanding of the variability and correctness of these responses is still insufficient especially for BVOCs other than isoprene (Niinemets et al., 2010). There is increasing evidence that sesquiterpenes (SQTs) and other semi-volatiles are commonly emitted from vegetation but are largely underestimated or overlooked due to methodological constraints (e.g. Bouvier-Brown et al., 2009; Ciccioli et al., 1999; Geron and Arnts, 2010; Haapanala et al., 2009; Helmig et al., 2007; Ortega et al., 2008). To date, the prediction of these emissions by common modeling approaches is uncertain. The light responses of SQT emissions are not exactly known although evidence for light dependency has been reported in some studies (see Duhl et al., 2008 and Geron and Arnts, 2010 for overviews). Likewise, a wide array of values of the temperature dependence coefficient $\beta$ (i.e. the slope of the emission increase with temperature increase assuming a log-linear relationship) has been reported for SQT emissions ranging over one order of magnitude between 0.03 and $0.4 \mathrm{~K}^{-1}$ with mean values around $0.17 \mathrm{~K}^{-1}$ (Duhl et al., 2008; Ortega et al., 2008). One reason for the uncertainty and variability in SQT emissions responses to light and temperature is that only few studies have investigated these responses under true environmentally controlled conditions and, even then, over a rather limited light and temperature range (Gouinguené and Turlings, 2002; Schuh et al., 1997). Most studies have deduced temperature responses of SQT emissions from field measurements, during which light and temperature effects could not be well separated (e.g. Helmig et al., 2006, 2007; Tarvainen et al., 2005). Furthermore, SQTs are synthesized in a pathway and cellular compartment different to that of isoprene and MTs, whose metabolic control and link to primary metabolites are less understood. In fact, plants often produce and emit SQTs and other semi-volatiles in response to biotic and abiotic stresses (Holopainen and Gershenzon, 2010; Laothawornkitkul et al., 2009; Loreto and Schnitzler, 2010). Other sources of emission variation such as the stress dose dependent induction kinetics (e.g. Copolovici et al., 2011; Staudt et al., 2010) or endogenous circadian clocks (e.g. Kunert et al., 2002) come into play and thus veil possible short-term light and temperature effects on emissions.

Even for emissions of isoprene, the by far best studied BVOC, the intra and inter-specific variability of the light and temperature responses is still far from being completely understood (Niinemets et al., 2010). Several studies have shown that the shapes of the light and temperature responses can vary with the prevailing climate conditions and the leaf's and the plant's micro habitat (Harley et al., 1996, 1997, 2004; Lerdau and Throop, 1999; Monson et al., 1992) as well as with the speed of temperature change (Singsaas et al., 1999) and duration of temperature exposure (Guenther et al., 1993). Empirical estimates of the variation in the temperature response with past history of temperature and of the variation in the light response with past history of light and leaf canopy position have been developed and incorporated in emission models (Guenther et al., 2006). However, light and temperature may have also interactive effects on their emission response curves. Most studies investigated light responses of BVOC emissions only at one temperature level and temperature responses only at one light level (e.g. Wang et al., 2007) thus neglecting the possibility that the emission response to one factor could be modulated by the other. Such interactive modulations of light and temperature responses may have important implications for the prediction of BVOC fluxes, because temperature and light vary throughout the 
day, seasons and weather conditions. Evidence for light and temperature interdependencies was first brought out by Tingey et al. (1979, 1987), who determined light responses of isoprene emissions from oaks and ferns at different temperatures and temperature responses at different light levels. However, these earlier works did not evaluate the response curves on a relative scale. Later, Monson et al. (1992) studied light responses of isoprene emissions from velvet bean at two temperatures and observed that the slope of the initial linear section (i.e. the quantum yield of isoprene emission) was significantly increased at high assay temperature. By contrast, no clear temperature and light interdependencies in the normalized response curves of isoprene emissions were reported in the studies by Guenther et al. (1991) on eucalyptus and by Harley et al. (1997) on oaks. Nevertheless, Guenther et al. (1991) outlined that considerable uncertainty and variability in the response curves exists in the high temperature ranges possibly associated with the unpredictable inactivation of isoprene synthase occurring at temperatures around and beyond $40^{\circ} \mathrm{C}$. Recently, Rasulov et al. (2010) - using a novel approach to determine the chloroplastic pool size of the isoprene synthase substrate - suggested that the temperature response of isoprene emission mirrors a combined effect of isoprene synthase activity and substrate limitations. Especially at high temperatures supraoptimal for photosynthetic processes, but not for the activity of rate-limiting enzymes in the chloroplastic BVOC biosynthesis pathway, emissions of chloroplastic isoprenoids could become partly or totally substrate limited. Accordingly, one may expect that at high temperatures emissions increase faster and saturate earlier in response to light than at moderate temperatures. Analogously, the temperature optimum in the temperature response of emissions could become lower at low light than at saturating light due to the dependence of substrate regeneration on photosynthetic processes. Alternatively, high incident light levels may intensify heat stress by enhancing leaf temperatures and generating photo-oxidative stress inside the chloroplasts (Demmig-Adams and Adams, 2006; Singsaas et al., 1999), which in turn could accelerate the inhibition of photosynthesis and enzyme activites in the chloroplastic BVOC biosynthesis pathway. Consequently, the temperature optimum of chloroplastic isoprenoid emissions would decrease under high light while the emissions of stress-induced BVOC such as SQTs may increase.

To address these questions we studied light and temperature responses of BVOC emissions, photosynthesis and chlorophyll fluorescence on Quercus coccifera, an evergreen Mediterranean oak closely related to $Q$. ilex (Bellarosa et al., 2005). Both oaks have been reported to emit MTs in a way similar to isoprene (Hansen and Seufert, 1996; Niinemets et al., 2002) as well as to emit some oxygenated MTs and SQTs (Ormeño et al., 2007, 2009; Staudt and Lhoutellier, 2007). We determined temperature responses at low light $\left(150 \mu \mathrm{mol} \mathrm{m}{ }^{-2} \mathrm{~s}^{-1}\right.$ Photosynthetic Photon Flux Density (PPFD)) and at high light $\left(1000 \mu \mathrm{mol} \mathrm{m}^{-2} \mathrm{~s}^{-1}\right.$ PPFD) that presumably correspond to non-saturating and saturating light levels for BVOC emissions and photosynthesis. Light responses were determined at $30^{\circ} \mathrm{C}$ and at $37^{\circ} \mathrm{C}$. $37^{\circ} \mathrm{C}$ was expected to be close to the optima of the activity of isoprenoid synthases (Grote et al., 2006) and to be supraoptimal for photosynthesis, whereas $30^{\circ} \mathrm{C}$ was expected to be close to the temperature optimum of photosynthesis of warm adapted plants. Furthermore, $30^{\circ} \mathrm{C}$ and $1000 \mu \mathrm{mol} \mathrm{m}{ }^{-2} \mathrm{~s}^{-1}$ PPFD represent the standard light and temperature conditions commonly applied in BVOC emission studies and models (Niinemets et al., 2010, 2011).

\section{Material and methods}

\subsection{Plants and plant enclosure system}

All experiments were conducted using potted 3-yr old kermes oak saplings grown from acorns collected in natural populations of the Herault and Gard departments in Southern France. Saplings of similar size and age were randomly selected to run light and temperature response curves. Plants were kept in a non-air conditioned greenhouse, fertilized with Osmocote Plus 12-14 M (15\% N, 3.5\% P, $9 \% \mathrm{~K}$, $1.2 \% \mathrm{MG}+$ trace elements) and regularly watered during the experimental period.

Response-curves of foliar BVOC emissions to light and temperature were determined by means of a dynamic, temperature and light controlled enclosure system consisting of a flat rectangular chamber of approx. $105 \mathrm{ml} \mathrm{vol}$ $(10.5 \times 5 \times 2 \mathrm{~cm})$. The chamber was made of a double walled water-jacketed stainless steel frame and a lid holding a $50 \mu \mathrm{m}$ PTFE-film. Chamber and lid were equipped with silicon gaskets to ensure tightness and fine nylon nets to maintain leaves in horizontal position. Homogenous mixing of the chamber air was maintained by a small PTFE fan inserted through the chamber bottom. The chamber was continuously flushed with compressed air (Ingersoll Rand compressor Mod. 49810187) at a constant rate of $0.51 \mathrm{~min}^{-1}$ (regulated by a Brooks 5815 mass flow controller), which was cleaned and dried in a clean air generator (AIRMOPURE, Chromatotec, France) and re-humidified to a achieve relative humidity of 30 to $60 \%$ in the chamber outlet by bypassing a variable portion of the air stream through a washing bottle. Chamber and plant were illuminated with a white light source (OSRAM $1000 \mathrm{~W}$ ) filtered by a $5-\mathrm{cm}$ water bath. Variation in chamber illumination was achieved by changing the distance between light source and chamber, and by covering the chamber with neutral density filters (Kodak Wratten Gelatin Filters). Chamber air temperature was regulated by a temperature controller (STATOP 4849, Chauvin Arnaux), whose output was connected to a modified heating unit of a laboratory water-bath, which circulated water through the chamber frame. Input temperature was measured by a thermocouple (Chrom-Constantan, OMEGA) inserted through a 
small hole in the chamber bottom. A second thermocouple was clamped inside to assess leaf temperature. These data were however not considered in the data evaluation, because the temperature difference between the two thermocouples was small $\left(<0.5^{\circ} \mathrm{C}\right)$ and variable, obviously unrelated to true leaf-to-air temperature differences. The whole system was installed in an air-conditioned laboratory adjacent to the greenhouse. During temperature response measurements, the air temperature of the laboratory was progressively increased by about $10^{\circ} \mathrm{C}$ to avoid water condensation in sampling lines and instruments.

\subsection{Photosynthesis and chlorophyll fluorescence measurements}

Chlorophyll fluorescence was measured on the leaves of the shoot used for BVOC emission measurements by means of a pulse-modulated fluorometer (PAM-2000, Walz, Germany). Maximum photochemical efficiency of photosystem II $(\mathrm{Fv} / \mathrm{Fm})$ was determined in the morning prior running a light or temperature response and again the following morning. Leaves were equipped with Walz leaf clips in the evening before and left in the dark overnight. Fv/Fm is defined as (Fm-Fo)/Fm where Fo is the initial fluorescence and Fm the maximal fluorescence of a dark-adapted leaf. Fo was measured under weak red modulated irradiance, and Fm under a saturated pulse of white light (approx. $10000 \mu \mathrm{mol} \mathrm{m}^{-2} \mathrm{~s}^{-1}$ PPFD). Fv/Fm of dark-adapted leaves reflect the potential quantum yield of photosystem II with optimal values of around 0.83 (Maxwell and Johnson, 2000). Lower values after stress exposure indicate persistent photoinhibition.

Further the actual quantum yield ( $\left.\Phi_{\text {PSII }}\right)$ of the photosystem II in light adapted leaves was determined on the enclosed measurement leaves during light and temperature ramping. $\Phi_{\text {PSII }}$ is defined as (Fm'-Ft)/Fm' where $\mathrm{Ft}$ is the measured fluorescence of a light adapted leaf and Fm' the maximum fluorescence after a pulse of saturating light. For $\Phi_{\mathrm{PSII}}$ determination the fluorescence probe was positioned above an enclosed leaf without shading it by pressing the head of the probe on the Teflon film in a way to reach a distance and an angle to the leaf plane of approximately $5 \mathrm{~mm}$ and $50^{\circ}$. $\Phi_{\text {PSII }}$ was measured three times on every enclosed leaf (in 5 min intervals) taking care to spot different parts of the leaf lamina each time. The mean of all measurements were used for further evaluation after eventual removal of outliers.

$\mathrm{Fv} / \mathrm{Fm}$ and $\Phi_{\text {PSII }}$ data were used to assess the apparent electron transport rate (ETR) and the nonphotochemical quenching of fluorescence (NPQ, Stern-Volmer relationship). ETR was calculated as: $\mathrm{ETR}=0.85 \times \mathrm{PPFD} \times 0.5 \Phi_{\mathrm{PSII}}$ where 0.85 and 0.5 are assumed correction factors for the incident light absorbed by the leaf and for the light distribution between the two photosystems. NPQ was calculated as (Fm-Fm')/Fm'. NPQ reflects heat-dissipation of excitation energy in the antenna system. At saturating light, NPQ values range typically between 1 and 4 (Demmig-Adams and Adams, 2006; Maxwell and Johnson, 2000).

Photosynthesis (net- $\mathrm{CO}_{2}$-assimilation, $A_{\mathrm{n}}$ ) and transpiration were measured by drawing a constant portion of the inlet and outlet air through a CI-301 infrared $\mathrm{CO}_{2}$ gas analyzer run in absolute mode (CID Inc., Camas, WA, USA) via tubes enclosing two humidity sensors with integrated temperature probes (HIH-3602C, Honeywell Inc., IL, USA). $\mathrm{CO}_{2}$ and humidity data were recorded three times during the period of VOC sampling. $A_{\mathrm{n}}$ and transpiration were calculated according to von Caemmerer and Farquhar (1981).

\subsection{BVOC emission measurements}

BVOCs were trapped by directing air exiting the chamber through a cartridge filled with about $200 \mathrm{mg}$ of the adsorbant Tenax TA (20-35 mesh, Chrompack) at a constant flow rate of $0.11 \mathrm{~min}^{-1}$. The cartridge was directly inserted in the chamber outlet (via a T-fitting) to minimize memory effects caused by BVOC adsorption in sampling lines. The sampling volume was set to a value between 0.5 and 2.01 according to the expected emission strength. The cartridges were analysed by Gas Chromatography with Flame Ionisation Detector (GC-FID) using a Chrompack CP9003 GC equipped with a Chrompack TCT4002 thermo-desorber (all Varian Inc.). Before desorption, tubes were pre-flushed with pure nitrogen (flow $30 \mathrm{ml} \mathrm{min}^{-1}$ ) for $1 \mathrm{~min}$ at room temperature to remove excessive humidity. To sustain peak identification of GC-FID measurements, additional BVOC samples (two per response curve) were taken on Perkin Elmer adsorption cartridges (300 mg Tenax TA, 2035 mesh, Chrompack) for GC analyses coupled with mass spectrometry (Varian CP3800/Saturn2000 MS equipped with a Perkin-Elmer Turbomatrix thermo-desorber). Both GCs were run with the same analytical set-up and program to obtain comparable chromatograms. VOCs were separated on a Chrompack Sil 8CB low bleed capillary column $(30 \mathrm{~m} \times 0.25 \mathrm{~mm})$ using the following temperature program: $3 \mathrm{~min}$ at $40^{\circ} \mathrm{C}, 3^{\circ} \mathrm{C} \mathrm{min}^{-1}$ to $100^{\circ} \mathrm{C}, 2.7^{\circ} \mathrm{C} \mathrm{min}^{-1}$ to $140^{\circ} \mathrm{C}, 2.4^{\circ} \mathrm{C} \mathrm{min}^{-1}$ to $180^{\circ} \mathrm{C}, 6^{\circ} \mathrm{C} \mathrm{min}^{-1}$ to $250^{\circ} \mathrm{C}$. The eluting compounds were identified by comparison of mass spectra and arithmetic retention indices with the NIST mass spectra library and Adams (2007) as well as with the databases developed from our institute for the instruments obtained from authentic standards (Fluka, Sigma, Bedoukin). Compounds were quantified from FID data using average per-ng-response-factors per compound class. The GCs were calibrated by injecting an aliquot of freshly prepared BVOC solution (pure standards dissolved in $\mathrm{MeOH}$ ) in a glass liner connected to a clean adsorbant cartridge and immediately purged with pure $\mathrm{N}_{2}$ for $10 \mathrm{~min}$ (flow rate $30 \mathrm{ml} \mathrm{min}^{-1}$ ). 


\subsection{Experimental protocol}

We intended to determine response curves reflecting steady state emissions. To ensure that emissions came to a new equilibrium after temperature or light changes, an equilibration time of approx. $1 \mathrm{~h}$ was applied between two successive measurements. This assumption was based on the results from previous kinetic studies on Holm oak (Staudt et al., 2003). Furthermore, we conducted preliminary experiments to assess the inertia of the plant and system response by following the decline of BVOC concentrations inside the chamber after light-to-dark transitions at constant temperature. The results showed that memory effects were small. After $1 \mathrm{~h}$, concentrations of non-oxygenated and oxygenated monoterpenes were respectively decreased to $1-2 \%$ and $2-8 \%$ of their initial values.

Response curves of BVOC emissions to light and temperature were determined on the terminal shoots of the saplings using for each response curve a different sapling. For measurement, the terminal shoot consisting of 4 to 7 leaves was mounted in the chamber early in the morning and the response curve was run afterwards usually between 10:00 a.m. and 06:00 p.m LT. The responses to light were measured by stepwise increasing PPFD between 0 and approx. $2000 \mu \mathrm{mol} \mathrm{m} \mathrm{m}^{-2} \mathrm{~s}^{-1}$ at a constant temperature of $30 \pm 0.2{ }^{\circ} \mathrm{C}$ in the first series and at $37 \pm 0.2{ }^{\circ} \mathrm{C}$ in the second series. The responses of BVOC emissions to temperature were measured by increasing the chamber temperature in $5^{\circ} \mathrm{C}$ increments from 20 to $50^{\circ} \mathrm{C}$ under two constant PPFD levels, once at approximately $150 \mu \mathrm{mol} \mathrm{m}^{-2} \mathrm{~s}^{-1}$ and once at approx. $1000 \mu \mathrm{mol} \mathrm{m} \mathrm{m}^{-2} \mathrm{~s}^{-1}$. Background BVOC in the empty chamber was measured at least once a day. In addition complete light or temperature ramps of the empty chamber were run. At the end of a measurement series, the enclosed leaves were cut off to determine the projected leaf area with an optical area meter (Delta-T devices Ltd., Cambridge, UK). The leaves were then oven-dried at $60^{\circ} \mathrm{C}$ for at least $48 \mathrm{~h}$ to determine leaf dry weights.

\subsection{Data treatments}

The BVOC emission rate was calculated as the difference between the air concentration in the chamber enclosing a shoot and the concentration measured in the empty chamber multiplied by the airflow and divided by the projected leaf area $\left(\mathrm{ng} \mathrm{m}^{-2} \mathrm{~s}^{-1}\right.$ ) or leaf dry mass $\left(\mu \mathrm{g} \mathrm{g}^{-1} \mathrm{~h}^{-1}\right)$. The air concentration in a given VOC sample was calculated as the amount of VOC sampled on the cartridge divided by the sampling volume.

The emission model by Guenther et al. (1993) was used to examine the light and temperature responses and to simulate diurnal variations of BVOC emissions from kermes oak on the bases of climate data recorded at our field measuring site in Puechabon (http://www.cefe.cnrs.fr/fe/puechabon/index. $\mathrm{htm})$. For light dependant BVOC emissions, the emission rate $E$ at a temperature $T$ and incident light $L$ is given as: $E=E_{\mathrm{S}} C_{T} C_{L}$, where $E_{\mathrm{S}}$ is the mean emission rate at standard temperature $T_{\mathrm{S}}\left(303 \mathrm{~K}^{-1}\right)$ and standard light $\left(1000 \mu \mathrm{mol} \mathrm{m}{ }^{-2} \mathrm{~s}^{-1} \mathrm{PPFD}\right)$, also called emission factor or basal emission rate. $C_{T}$ and $C_{L}$ are dimensionless scaling factors correcting $E_{\mathrm{S}}$ to actual leaf temperature and incident light:

$$
\begin{aligned}
C_{T} & =\frac{\exp \left(C_{T 1}\left(T-T_{\mathrm{s}}\right) /\left(\mathrm{RTT}_{\mathrm{S}}\right)\right)}{1+\exp \left(C_{T 2}\left(T-T_{\mathrm{m}}\right) /\left(\mathrm{RTT}_{\mathrm{S}}\right)\right)}, \\
C_{L} & =\frac{C_{L 1} \alpha L}{\sqrt{1+\alpha^{2} L^{2}}} .
\end{aligned}
$$

In Eq. (2), $L$ is the incident light ( $\mu \mathrm{mol} \mathrm{m}{ }^{-2} \mathrm{~s}^{-1}$ PPFD), and $\alpha$ and $C_{L 1}$ are empirical coefficients. In Eq. (1), $T$ is the leaf temperature (Kelvin), $T_{\mathrm{S}}$ is the standard temperature $(303 \mathrm{~K})$ and $R$ the gas constant $\left(8.134 \mathrm{~J} \mathrm{~K}^{-1} \mathrm{~mol}^{-1}\right) . C_{T 1}, C_{T 2}$ and $T_{\mathrm{m}}$. are empirical coefficients, of which $C_{T 1}, C_{T 2}$ describe respectively the activation and deactivation energy $\left(\mathrm{J} \mathrm{mol}^{-1}\right)$ of the emission, and $T_{\mathrm{m}}(\mathrm{K})$ the temperature at which the emission rate is highest.

For BVOC emissions assumed to result only from the evaporation from BVOC storage tissues, the emission rate $E$ at a leaf temperature $T$ is given as: $E=E_{\mathrm{S}} C_{T}$ with:

$C_{T}=\exp \left(\beta\left(T-T_{\mathrm{s}}\right)\right)$

where $E_{\mathrm{S}}$ is the mean emission rate at standard temperature $T_{\mathrm{S}}\left(303 \mathrm{~K}^{-1}\right)$ and $\beta\left(\mathrm{K}^{-1}\right)$ is the coefficient describing the exponential increase of the emissions with temperature.

Coefficients of Eqs. (1) to (3) were determined by nonlinear regression analysis (Marquardt-Levenberg algorithm, SigmaStat 2.0 Jandel Scientific Software). Absence of differences between the light responses obtained at $30^{\circ} \mathrm{C}$ and $37^{\circ} \mathrm{C}$, and between the temperature responses obtained at 1000 and $150 \mu \mathrm{mol} \mathrm{m}^{-2} \mathrm{~s}^{-1}$ PPFD was tested by comparing the sum of residual sum of squares of individual fittings to each group of data with the residual sum of squares of the global fitting to pooled data. This was done using a Fisher's law with $(n-1) k$ and $(N-k)$ degrees of freedom, where $n$ is the number of individual fittings, $k$ is the number of coefficients and $N$ is the total number of data.

\section{Results}

\subsection{BVOC emission spectra}

On the whole more than $50 \mathrm{BVOCs}$ were detected in the emissions from $Q$. coccifera leaves. Most of them were isoprenoids. Among them were identified 14 non-oxygenated monoterpenes $(\alpha$-thujene, $\alpha$-pinene, camphene, sabinene, $\beta$-pinene, myrcene, $\alpha$-terpinene, cymene, limonene, $\beta$ phellandrene, eucalyptol, (Z)- and (E)- $\beta$-ocimene, $\gamma$ terpinene) and six oxygenated monoterpenes (linalool-oxide, terpinolene, linalool, borneol, terpinen-4-ol, $\alpha$-terpineol). 
Of 20 detected sesquiterpenes were identified $\alpha$-cubebene, $\alpha$-copaene, $\beta$-bourbonene, $\beta$-caryophyllene, $\alpha$-curcumene, $\delta$-cadinene, germacrene $\mathrm{D}, \alpha$-zingiberene, (E)- $\beta$-farnesene and $\alpha$-humulene. Tentatively identified in the emissions were cyclo-sativene, (Z)- $\alpha$-bergamotene, $\gamma$-muurolene, a $\alpha$-farnesene isomer as well as the sesquiterpene alcohols (E)-nerolidol and $\alpha$-cadinol. Furthermore we observed occasionally in the emissions isoprene, the homoterpene (E)-4.8-dimethyl-1.3.7-nonatriene, the aromatic compound methyl-salicylate and diverse green leaf volatiles namely 1pentenol, (Z)-3-hexenal, (Z)-3-hexenol, (E)-2-hexenol and (Z)-3-hexenyl-acetate (plus several other non-identified C5 and $\mathrm{C} 6$ compounds).

Under standard conditions foliar BVOC emissions from all measured Quercus coccifera plants were dominated by the monoterpenes $\alpha$-pinene, $\beta$-pinene, sabinene, myrcene, limonene, eucalyptol and (Z)- $\beta$-ocimene, which accounted for at least $90 \%$ of the total BVOC release. The relative abundance of these major compounds was somewhat different among the individual plants. Some plants emitted mainly myrcene or limonene and (Z)- $\beta$-ocimene, others a mix of pinenes, sabinene and eucalyptol. The relative abundance of some oxygenated monoterpenes and sesquiterpenes were also different among the emissions profiles of individuals and appeared to be correlated with the abundance of major compounds. For instance $\alpha$-terpineol was regularly emitted from trees emitting high fractions of eucalyptol and sabinene, but not from trees emitting predominantly myrcene or limonene. Instead linalool was regularly found in the emission of individuals dominated by myrcene. The relative fractions remained fairly stable over the measured temperature and light ranges except at highest temperatures (45 and $50^{\circ} \mathrm{C}$ ) and at lowest light levels when emission rates of individual compounds were close to the detection limit (data not shown). In the following we concentrate on the sum of non-oxygenated monoterpene hydrocarbons (MT-hc), sum of oxygenated monoterpenes (MT-ox), the sum of sesquiterpenes (SQT), and the sum of green leaf volatiles (GLVs). Individual compounds within each BVOC class showed similar trends in their responses. However, the oxygenated MT Eucalyptol behaved like MT-hc and therefore was grouped with these compounds.

\subsection{Light responses}

Emissions of all BVOC classes showed clear positive responses to light except for GLV emissions (Fig. 1). Highest emission rates of GLVs were usually seen during the first measurement in the dark. Subsequently, GLV emissions were very low $\left(<10 \mathrm{ng} \mathrm{m}^{-2} \mathrm{~s}^{-1}\right)$ throughout all light levels at either assay temperature. By contrast, emissions of all isoprenoids, i.e. MT-hc, MT-ox and SQT, were not or hardly detectable in the dark, steadily increased during the following light ramps up to maximum levels lying around 600 up to $1500 \mu \mathrm{mol} \mathrm{m}{ }^{-2} \mathrm{~s}^{-1}$ PPFD. Mean MT-hc emission rates tended to decrease at highest PPFD levels at $37^{\circ} \mathrm{C}$, which was not observed in the light response at $30^{\circ} \mathrm{C}$. Thus at $37^{\circ} \mathrm{C}$, MT-hc emissions seemed to saturate at lower light levels than at $30^{\circ} \mathrm{C}$. Compared to MTs, SQT emissions tended to saturate at lower light levels especially in the $30^{\circ} \mathrm{C}$-series. The variability of SQT emissions among replicates was much lower in the $30^{\circ} \mathrm{C}$-series than in the $37^{\circ} \mathrm{C}$-series. In the $37^{\circ} \mathrm{C}$-series one plant showed considerably higher SQT emissions (up to $100 \mathrm{ng} \mathrm{m}^{-2} \mathrm{~s}^{-1}$ consisting mainly of Germacrene D) than the two other replicates $\left(<30 \mathrm{ng} \mathrm{m}^{-2} \mathrm{~s}^{-1}\right)$.

$A_{\mathrm{n}}$ rates were also more scattered in the light response at $37^{\circ} \mathrm{C}$ and on average lower than in the light response at $30^{\circ} \mathrm{C}$ especially at highest PPFD. Transpiration rate increased with increasing light from about $0.3 \mathrm{mmol} \mathrm{m}^{-2} \mathrm{~s}^{-1}$ in the dark to values around $2.0 \mathrm{mmol} \mathrm{m}^{-2} \mathrm{~s}^{-1}$, and tended to decrease at highest PPFD levels in the $37^{\circ} \mathrm{C}$-series (data not shown). ETR values were higher in the $37^{\circ} \mathrm{C}$-series than in the $30^{\circ} \mathrm{C}$ series. At both assay temperatures, maximum ETR was observed during the last measurements at highest PPFD. NPQ remained very low at low light levels, gradually increased afterwards to reach a maximum at $2000 \mu \mathrm{mol} \mathrm{m}^{-2} \mathrm{~s}^{-1}$ PPFD. After night $\mathrm{Fv} / \mathrm{Fm}$ values ranged between 0.79 and 0.82 and were not significantly affected by light ramping at either assay temperature (data not shown).

\subsection{Temperature responses}

Emissions of all BVOC classes clearly responded to temperature changes except GLVs (Fig. 2). Emissions of GLVs were again highest during the first measurement $\left(20^{\circ} \mathrm{C}\right)$, remained subsequently very low between 25 and $45^{\circ} \mathrm{C}$ and increased only at $50^{\circ} \mathrm{C}$ especially under high assay PPFD. The temperature responses of MT-hc emissions showed the typical shape of an Arrhenius type response with an exponential increase at lower temperatures, a maximum between 35 and $45^{\circ} \mathrm{C}$ and a rapid decrease beyond this temperature. Up to $35^{\circ} \mathrm{C}$ mean emission rates were somewhat higher at high assay PPFD than at low assay PPFD, which can be attributed to the positive light influence on emissions (see above). However, peak emission rates of MT-hc were similar in both temperature responses (means around $1000 \mathrm{ng} \mathrm{m}^{-2} \mathrm{~s}^{-1}$ ) due to different responses in the high temperature range: under high assay PPFD, emissions of MT-hc peaked around $35^{\circ} \mathrm{C}$, dropped rapidly at higher temperatures and were very low at $50^{\circ} \mathrm{C}$. Under low assay PPFD, MT-hc emissions were maximal at 40 and $45^{\circ} \mathrm{C}$ and were still significant at $50^{\circ} \mathrm{C}$. Emissions of MT-ox and SQT increased exponentially up to 40 and $45^{\circ} \mathrm{C}$ at low assay PPFD and dropped at $50^{\circ} \mathrm{C}$ albeit relatively less than MT-hc emission. However, at high assay PPFD, average MT-ox and SQT emission rates somewhat decreased at $40^{\circ} \mathrm{C}$, and strongly re-increased at higher temperatures reaching peak emission rates at $50^{\circ} \mathrm{C}$.

At both assay PPFD, $A_{\mathrm{n}}$ and ETR showed a broad temperature maximum up to $35^{\circ} \mathrm{C}$ with higher values at high 

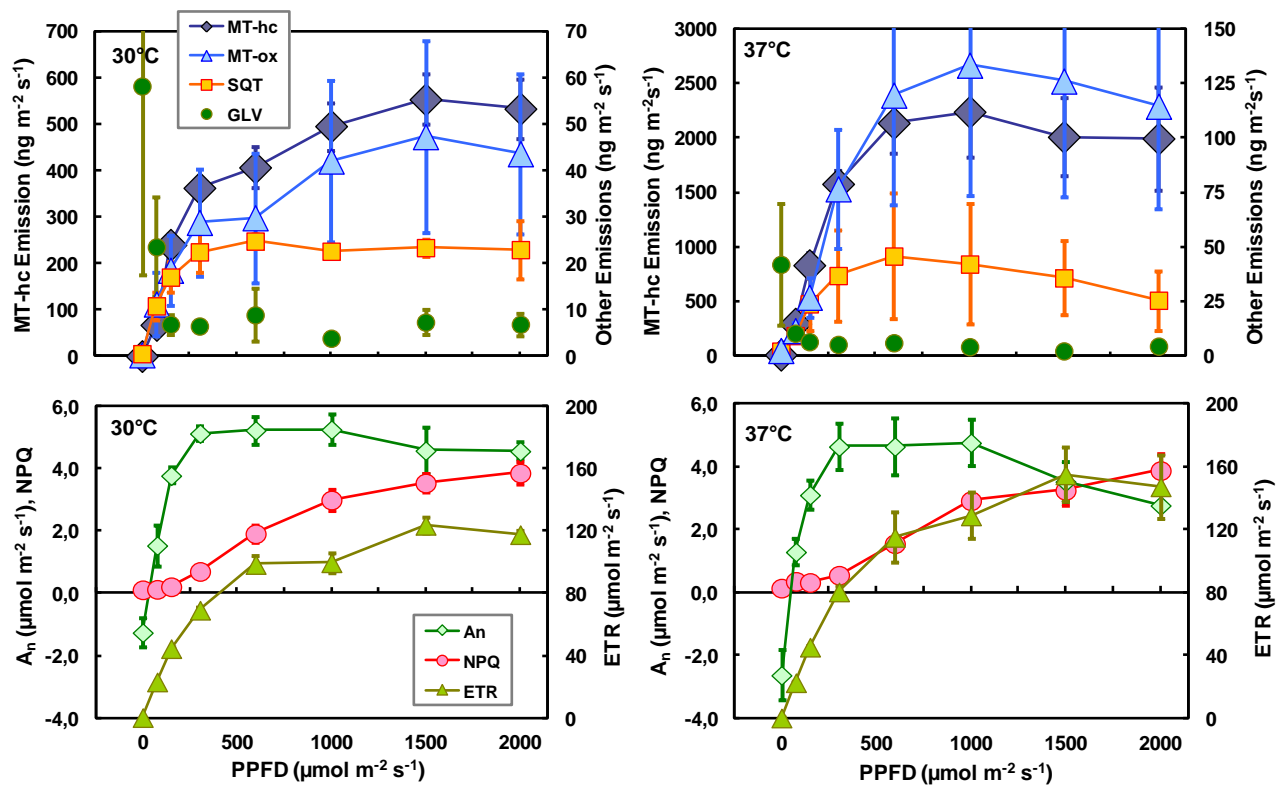

Fig. 1. Light responses of BVOC emissions (upper panels) and photosynthetic parameters (lower panels) of Q. coccifera leaves measured at two temperature levels of $30^{\circ} \mathrm{C}$ (left panels) and $37^{\circ} \mathrm{C}$ (right panels). Dark blue lozenges: monoterpene hydrocarbons (MT-hc); bright blue triangles: oxygenated monoterpenes (MT-ox); yellow squares: sesquiterpenes (SQT); dark green circles: green leaf volatiles (GLV); dark green lozenges: photosynthesis $\left(A_{\mathrm{n}}\right)$; green triangles: apparent photosystem II electron transport rate (ETR); red dots: non photochemical quenching (NPQ). Data are means \pm SD of $n=3-4$ replicates.

than at low assay PPFD (Fig. 2). At temperatures beyond $40{ }^{\circ} \mathrm{C} A_{\mathrm{n}}$ and ETR rapidly declined and this decrease was more pronounced at high assay PPFD than at low assay PPFD. For example at $50^{\circ} \mathrm{C} A_{\mathrm{n}}$ rates were decreased to $-1.1 \pm 0.4 \mu \mathrm{mol} \mathrm{m}{ }^{-2} \mathrm{~s}^{-1}$ (i.e. net respiration) and $-0.3 \pm 0.1 \mu \mathrm{mol} \mathrm{m} \mathrm{m}^{-2} \mathrm{~s}^{-1}$ under high PPFD and low PPFD respectively. At low assay PPFD, NPQ remained low up to $40^{\circ} \mathrm{C}$ and readily increased at higher temperatures. By contrast in the temperature response at high PPFD, NPQ was augmented already at moderate temperatures and hardly increased at highest temperatures. $\mathrm{Fv} / \mathrm{Fm}$ values of leaves having experienced a temperature ramp at low assay PPFD almost completely recovered to initial levels $(0.79 \pm 0.01$ vs. $0.81 \pm 0.02$ ), while those having experienced a temperature ramp at high assay PPFD were significantly reduced $(0.59 \pm 0.13$ vs. $0.80 \pm 0.02)$. In particular one replicate had very low $\mathrm{Fv} / \mathrm{Fm}$ values. This plant showed also the strongest drop in $A_{\mathrm{n}}$ at high temperatures accompanied by a burst of MT-ox and GLVs. Overall, the decrease in MT-hc emissions between 40 and $50^{\circ} \mathrm{C}$ was correlated with the decrease in $A_{\mathrm{n}}$ or ETR at either assay PPFD $\left(R^{2}: 068-0.86, n=9\right.$, data not shown). Transpiration data (not shown) were rather scattered over the whole range of temperatures, but tentatively increased with increasing temperature, especially at low assay PPFD.

\subsection{Simulations}

Data shown in Figs. 1 and 2 indicated that light and temperature responses of BVOC emissions differed between BVOC classes and were modified by light-temperature interactions. Yet, individual replicates largely differed in their absolute emission rates thus causing a considerable data scattering and uncertainty in the emissions responses. In order to test whether the observed trends hold on a relative scale and can be simulated by commonly used light and temperature algorithms, the emission data of light and temperature responses were respectively normalized to $30^{\circ} \mathrm{C}$ and 1000 PPFD and fitted to Eqs. (1) to (3). For the sake of simplification, MT-ox and SQT data were pooled to one class of semivolatiles $(\mathrm{SV}=\mathrm{MT}-\mathrm{ox}+\mathrm{SQT})$, as these expressed comparable responses.

Light responses of relative MT-hc emission rates showed similar trends as absolute emissions (Fig. 3): relative emission rates leveled off later in the $30^{\circ} \mathrm{C}$ temperature algorithms, the than in the $37^{\circ} \mathrm{C}$ series, during which emissions somewhat declined at highest PPFD. However, because the light function (Eq. 2) can only simulate an asymptotic response, curve fitting on MT-hc emission data gave only marginally different response curves for the $30^{\circ} \mathrm{C}$ and $37^{\circ} \mathrm{C}$ series $(P<0.1)$. Moreover, it cannot be ruled out that small unaccounted memory effects and leaf temperature variations have influenced the light responses. Nevertheless, compared to the $30^{\circ} \mathrm{C}$ series the coefficient $\alpha$ was somewhat higher at 

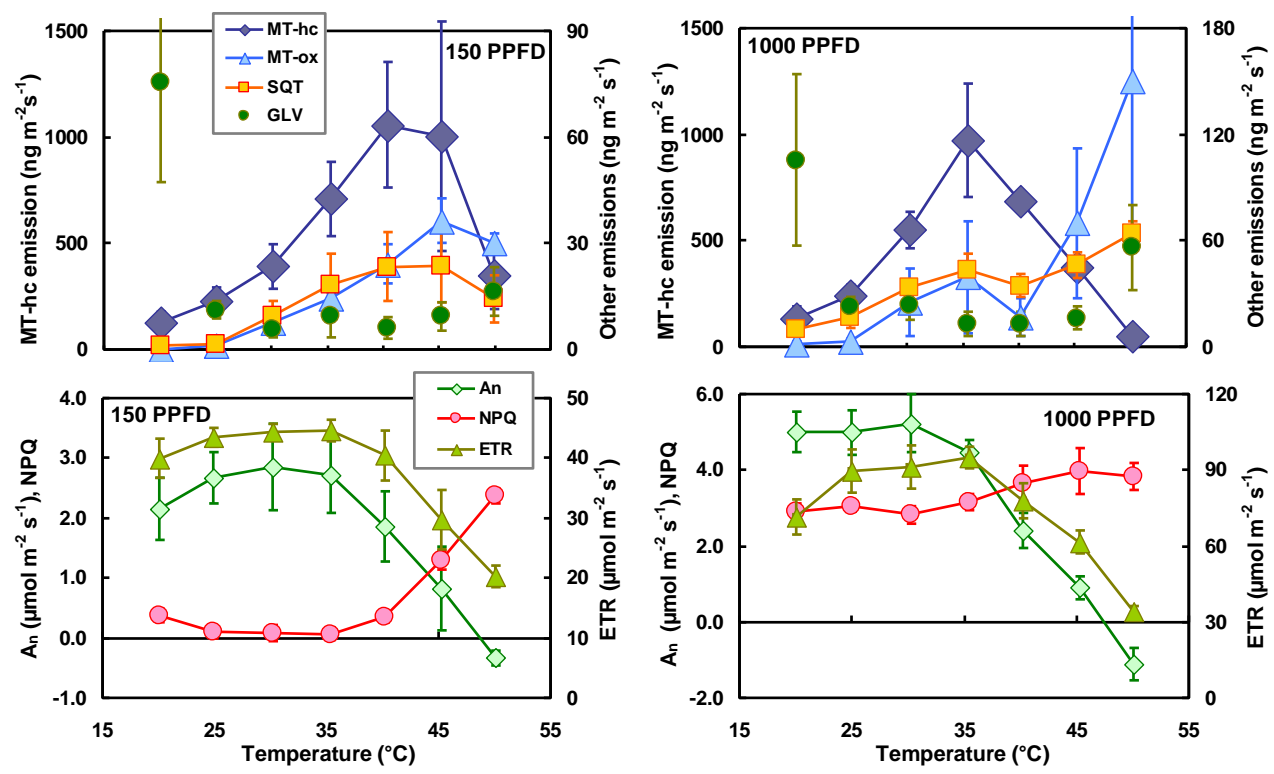

Fig. 2. Temperature responses of BVOC emissions (upper panels) and photosynthetic parameters (lower panels) of $Q$. coccifera leaves measured at two light levels of 150 (left panels) and 1000 (right panels) $\mu \mathrm{mol} \mathrm{m} \mathrm{m}^{-1}$ PPFD. Dark blue lozenges: monoterpene hydrocarbons (MT-hc); bright blue triangles: oxygenated monoterpenes (MT-ox); yellow squares: sesquiterpenes (SQT); dark green circles: green leaf volatiles $(\mathrm{GLV})$; dark green lozenges: photosynthesis $\left(A_{\mathrm{n}}\right)$; green triangles: apparent photosystem II electron transport rate (ETR); red dots: non photochemical quenching (NPQ). Data are means \pm SD of $n=3$ replicates.

$37^{\circ} \mathrm{C}$ than at $30^{\circ} \mathrm{C}(0.0323$ vs. 0.0279$)$ yielding a response curve with a slightly steeper increase and earlier saturation level. Relative emissions of SV largely scattered in both series resulting in almost identical response curves with relatively low light saturation levels in all cases.

Contrary to the light responses, temperature responses of relative MT-hc and SV emissions shared little similarity (Fig. 3). For both BVOC classes, curves fitted on individual series were significantly different from the combined fits $(P<0.001)$. The predicted temperature optimum $T_{\mathrm{m}}$ of MThc emissions was more than $6^{\circ} \mathrm{C}$ higher under low than under high assay PPFD (44.1 vs. $\left.37.6^{\circ} \mathrm{C}\right)$. Even higher $T_{\mathrm{m}}$ were predicted for $\mathrm{SV}$ emissions with values of $47^{\circ} \mathrm{C}$ and $70^{\circ} \mathrm{C}$ at low and high assay PPFD respectively. In fact, at high assay PPFD the fitted Arrhenius temperature function assumed for light dependent BVOC emissions (Eq. 1) suggested a quasi exponential increase of SV emissions ignoring the small initial emission peak observed at $35^{\circ} \mathrm{C}$. Fitting an exponential temperature response (Eq. 3 ) to the data yielded slopes $\beta$ of $0.09 \mathrm{~K}^{-1}\left(R^{2}=0.70\right)$ and $0.135 \mathrm{~K}^{-1}\left(R^{2}=0.80\right)$ for the temperature responses of $\mathrm{SV}$ emissions at high and low assay PPFD respectively. SV emissions appeared to respond relatively stronger to temperature at low than at high assay PPFD, basically because of extremely low emission rates at 20 and $25^{\circ} \mathrm{C}$ in the low assay PPFD series.
To illustrate the potential effect of the interaction of light and temperature responses on BVOC emission predictions, diurnal emission patterns were calculated from climatic data of a hot summer day recorded in the forest station of Puechabon (Fig. 4). Average $E_{\mathrm{S}}$ values deduced from all measurements (MT-hc: $738 \mathrm{ng} \mathrm{m}^{-2} \mathrm{~s}^{-1}$, SV: $63 \mathrm{ng} \mathrm{m}^{-2} \mathrm{~s}^{-1}$ ) were applied and considered to be constant throughout the day. Emission rates were calculated in two ways: first by assuming constant light and temperature responses using the global parameters obtained from curve fittings on pooled data sets (dashed lines in Fig. 3), and second by assuming changing light and temperature responses during the course of the day (straight lines in Fig. 3). In the latter case, we applied the temperature and light response curves obtained at the low light and temperature levels for the hours before 08:00 and after 18:00 GMT, the temperature and light responses curves obtained at the high light and temperature levels for the hours between 09:00 and 16:00 GMT, and the global temperature and light responses curves for the hours in between. Differences between the two simulations were negligibly small outside the hottest and brightest hours of the day, because all light and temperature responses were found to be similar in the lower light and temperature ranges (cf. Fig. 3). However, large differences occurred during midday hours when emissions are expected to be highest. While the simulation with fixed responses predicted a typical dome-shaped emission course, the simulation with adjusted responses predicted rather a plateau with a slight depression around midday. 

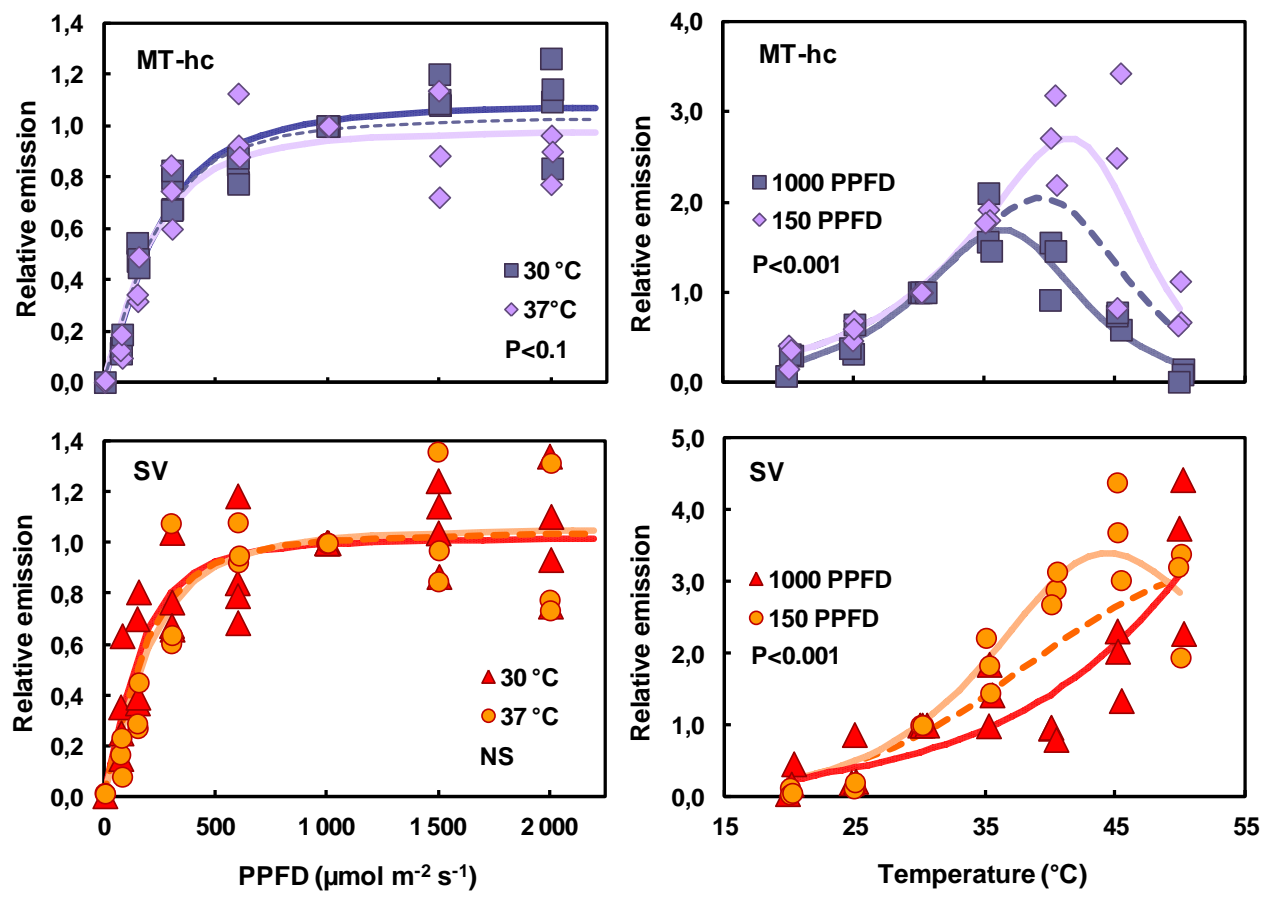

Fig. 3. Light (left) and temperature (right) responses of MT-hc (upper panels) and SV emissions (lower panels) of $Q$. coccifera leaves determined at two different temperature levels $\left(30\right.$ and $\left.37^{\circ} \mathrm{C}\right)$ and two light levels $\left(150\right.$ and $\left.1000 \mu \mathrm{mol} \mathrm{m}{ }^{-2} \mathrm{~s}^{-1} \mathrm{PPFD}\right)$. Emission data of each temperature and light response were normalised to respectively $30^{\circ} \mathrm{C}$ and $1000 \mu \mathrm{mol} \mathrm{m}^{-2} \mathrm{~s}^{-1} \mathrm{PPFD}$. Curves are simulations obtained by curve fitting using the temperature and light equations described in M\&M (see Eqs. 1 and 2) either on individual data sets (straight lines) or combined data sets (dotted lines). P-values annotate the statistical probability individual fits are different from global fits (NS: Not Significant). The deduced coefficients are as follows: Light responses: $\mathrm{MT}$-hc $30^{\circ} \mathrm{C}: \alpha=0.00279$, $C_{L 1}=1.086\left(R^{2}=0.95\right)$, MT-hc $37^{\circ} \mathrm{C}: \alpha=0.00323, C_{L 1}=0.984\left(R^{2}=0.91\right)$; MT-hc $30+37^{\circ} \mathrm{C}: \alpha=0.0030, C_{L 1}=1.039\left(R^{2}=0.93\right)$; SV $30^{\circ} \mathrm{C}: \alpha=0.00427, C_{L 1}=1.023\left(R^{2}=082\right)$; SV $37^{\circ} \mathrm{C}: \alpha=0.00333, C_{L 1}=1.057\left(R^{2}=0.83\right) ; \mathrm{SV} 30+37^{\circ} \mathrm{C}: \alpha=0.00376, C_{L 1}=1.04$ $\left(R^{2}=0.82\right)$. Temperature responses: MT-hc 150 PPFD: $C_{T 1}=87452 \mathrm{~J} \mathrm{~mol}^{-1}, C_{T 2}=313882 \mathrm{~J} \mathrm{~mol}-1, T_{\mathrm{m}}=317 \mathrm{~K}\left(R^{2}=0.78\right)$, MThc 1000 PPFD: $C_{T 1}=120836 \mathrm{~J} \mathrm{~mol}^{-1}, C_{T 2}=296030 \mathrm{~J} \mathrm{~mol}^{-1}, T_{\mathrm{m}}=310.6 \mathrm{~K}\left(R^{2}=0.90\right)$; MT-hc $150+1000$ PPFD: $C_{T 1}=89795 \mathrm{~J} \mathrm{~mol}-1$, $C_{T 2}=266262 \mathrm{~J} \mathrm{~mol}^{-1}, T_{\mathrm{m}}=314.6 \mathrm{~K}\left(R^{2}=0.58\right)$; SV 150 PPFD: $C_{T 1}=110121 \mathrm{~J} \mathrm{~mol}^{-1}, C_{T 2}=189164 \mathrm{~J} \mathrm{~mol}{ }^{-1}, T_{\mathrm{m}}=316.7 \mathrm{~K}\left(R^{2}=0.92\right)$, SV 1000 PPFD: $C_{T 1}=69025 \mathrm{~J} \mathrm{~mol}^{-1}, C_{T 2}=7287 \mathrm{~J} \mathrm{~mol}^{-1}, T_{\mathrm{m}}=343.5 \mathrm{~K}\left(R^{2}=0.76\right) ; \mathrm{SV} 150+1000 \mathrm{PPFD} C_{T 1}=103056 \mathrm{~J} \mathrm{~mol}-1$, $C_{T 2}=107104 \mathrm{~J} \mathrm{~mol}^{-1}, T_{\mathrm{m}}=314.2 \mathrm{~K}\left(R^{2}=0.72\right)$.

Integrated over the day, the MT-hc release was about $21 \%$ lower when simulated with variable responses instead of constant responses $\left(41.8 \mathrm{mg} \mathrm{m}^{-2} \mathrm{~d}^{-1}\right.$ vs. $\left.50.6 \mathrm{mg} \mathrm{m}^{-2} \mathrm{~d}^{-1}\right)$. SV release was also lower in the simulation with variable responses than with constant responses $\left(3.3 \mathrm{mg} \mathrm{m}^{-2} \mathrm{~d}^{-1}\right.$ vs. $4.5 \mathrm{mg} \mathrm{m}^{-2} \mathrm{~d}^{-1}$ ), because the global temperature response of $\mathrm{SV}$ emissions predicts a stronger emission increase during the hottest hours than the individual temperature response at high PPFD (Fig. 3). However, unlike assumed in the simulation, it is possible that $E_{\mathrm{S}}$ of $\mathrm{SV}$ emissions is not constant throughout the day but increases under high irradiance levels. The mean $E_{\mathrm{S}}$ of SV emissions deduced from the temperature response curves (Fig. 2) was more than two times higher at high PPFD than at low PPFD (62 vs. $27 \mathrm{ng} \mathrm{m}^{-2} \mathrm{~s}^{-1}$ ).

\section{Discussion}

\subsection{Q. coccifera - a relevant emitter of monoterpenes and sesquiterpenes}

Kermes oak is a small circum-Mediterranean oak with small spiny tough evergreen leaves (Toumi and Lumaret, 2010) typically growing in patches each one amassing numerous stems of 0.5 to $1 \mathrm{~m}$ height. It is very abundant in post-fire communities of open highly degraded calcareous shrublands due to its strong resprouting ability and its deep root system (Kaye et al., 2010). As the Mediterranean climate is predicted to become drier and warmer during the 21th century (Giorgi and Lionello, 2008), Q. coccifera shrublands may substantially expand in future (Acacio et al., 2009), which could considerably alter BVOC budgets of these regions.

The $E_{\mathrm{S}}$ values calculated from all experiments for this species were on average $( \pm \mathrm{SD}) 13.1 \pm 6.9 \mu \mathrm{g} \mathrm{g}^{-1} \mathrm{~h}^{-1}$ for 


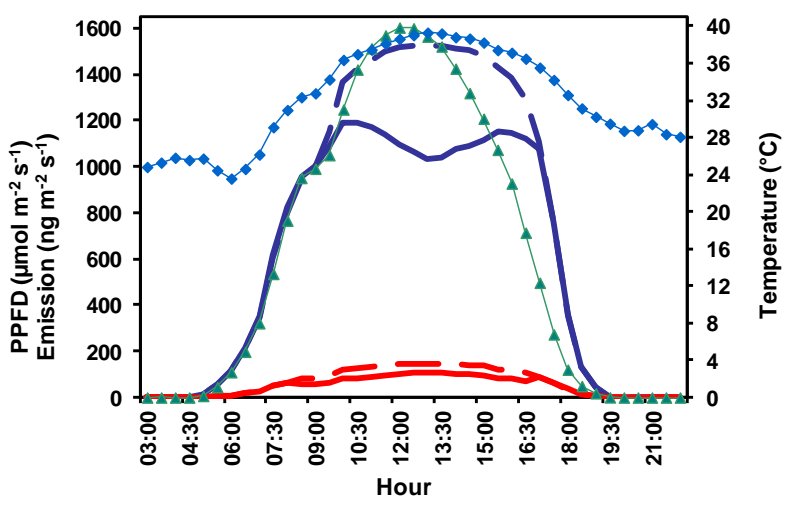

Fig. 4. Simulated MT-hc (purple) and SV (red) emissions from light (green) and temperature (blue) data recorded during a hot summer day over a Mediterranean oak forest in Southern France. Simulations were made by assuming either constant light and temperature responses of emissions (dashed lines) or variable responses (straight lines) using the parameters deduced from data sets given in Fig. 3 (see text for more details).

MT-hc $\left(738 \pm 378 \mathrm{ng} \mathrm{m}^{-2} \mathrm{~s}^{-1}\right.$ or $\left.5.4 \pm 2.8 \mathrm{nmol} \mathrm{m}^{-2} \mathrm{~s}^{-1}\right)$, $0.65 \pm 0.58 \mu \mathrm{g} \mathrm{g}^{-1} \mathrm{~h}^{-1}$ for MT-ox $\left(37 \pm 32 \mathrm{ng} \mathrm{m}^{-2} \mathrm{~s}^{-1}\right.$ or $\left.0.24 \pm 0.21 \mathrm{nmol} \mathrm{m}^{-2} \mathrm{~s}^{-1}\right)$, and $0.47 \pm 0.26 \mu \mathrm{gg}^{-1} \mathrm{~h}^{-1}$ for SQT $\left(27 \pm 15 \mathrm{ng} \mathrm{m}^{-2} \mathrm{~s}^{-1}\right.$ or $\left.0.13 \pm 0.07 \mathrm{nmol} \mathrm{m}^{-2} \mathrm{~s}^{-1}\right) . E_{\mathrm{S}}$ values of total MT emissions are in line with those reported in previous studies on the same species (Csiky and Seufert, 1999: 17.5 $\mathrm{g} \mathrm{g}^{-1} \mathrm{~h}^{-1}$; Llusia and Peñuelas, 2000: 2-6 $\mu \mathrm{g} \mathrm{g}^{-1} \mathrm{~h}^{-1}$; Owen et al., 2001: $5.7 \pm 2.3 \mu \mathrm{g} \mathrm{g}^{-1} \mathrm{~h}^{-1}$; Ormeño et al., 2009: $1.9 \pm 0.6 \mu \mathrm{g} \mathrm{g}^{-1} \mathrm{~h}^{-1}$; Karl et al., 2009: $\left.25 \mathrm{\mu g} \mathrm{g}^{-1} \mathrm{~h}^{-1}\right)$. In past studies, SQT emissions from $Q$. coccifera were only reported by Ormeño et al. $(2007,2009)$ with $E_{\mathrm{S}}$ values ranging between $<0.1$ to about $1 \mu \mathrm{gg}^{-1} \mathrm{~h}^{-1} . E_{\mathrm{S}}$ for SQT emissions of numerous other plant species were compiled by Duhl et al. (2008) and Ortega et al. (2008): Ortega et al. (2008) found SQT $E_{\mathrm{S}}$ ranging from $<0.01$ to $0.6 \mu \mathrm{g} \mathrm{g}^{-1} \mathrm{~h}^{-1}$ for deciduous trees and $E_{\mathrm{S}}$ ranging from $<0.01$ to $0.7 \mu \mathrm{g} \mathrm{g}^{-1} \mathrm{~h}^{-1}$ for conifers. Duhl et al. (2008) deduced default SQT $E_{\mathrm{S}}$ of $0.29 \pm 0.41,1.41 \pm 2.20$, $7.06 \pm 6.83$ and $0.19 \pm 0.43 \mu \mathrm{g} \mathrm{g}^{-1} \mathrm{~h}^{-1}$ for coniferous trees, broadleaf trees, shrubs, and crops respectively. Finally in a very recent study by Bracho-Nunez et al. (2011), SQT emissions were detected in six Mediterranean species with $E_{\mathrm{S}}$ values ranging from 0.03 to $3.33 \mu \mathrm{g} \mathrm{g}^{-1} \mathrm{~h}^{-1}$. Our SQT $E_{\mathrm{S}}$ values fall in the range of these literature data. In addition to MTs and SQTs we occasionally observed GLVs and traces of isoprene, homoterpenes, methyl-salicylate and other nonidentified compounds in the emissions. Under physiological normal conditions, emissions of SQTs and other non-MTs accounted for about $5 \%$ of the total amount of BVOCs released from $Q$. coccifera leaves. Together, our data confirm that kermes oak is similar to its close relative Holm oak a strong emitter of MTs (Csiky and Seufert, 1999; Hansen and
Seufert, 1996). There were relative large differences among individuals in both, quantity and quality of MT emissions, probably associated with inherent differences in the trees capacity to produce MTs, as it has been observed in populations of other MT emitting oak species (Staudt et al., 2004).

\subsection{Light and temperature responses and interactions}

Among the BVOCs emitted by $Q$. coccifera leaves, GLVs were the only ones expressing no clear light and temperature responses. GLVs stem from the peroxidation of free linoleic and linolenic acids, which are typically released from biomembranes upon wounding and exposure to heat, UV radiation and ozone (Matsui, 2006). In our study, relevant emissions of GLVs were only found in the first measurements within all series and in the measurements at $50{ }^{\circ} \mathrm{C}$ in combination with high assay PPFD. The first observation can be attributed to some mechanical stress leaves experienced when clamped inside the chamber, whereas the second one to membrane damages caused by heat and associated oxidative stress.

Emission rates of other BVOC classes - all isoprenoids - were found to be light and temperature dependent exhibiting responses curves more or less similar to those reported for isoprene emissions. This is not surprising for the emissions of MTs, because $Q$. coccifera leaves do not possess BVOC storing organs (Hansen and Seufert, 1996; Olivier et al., 2011). It is generally recognized that monoterpenes in BVOC non-storing plants are produced in the methylerythritol-phosphate (MEP) pathway located in chloroplasts, where photosynthetic processes provide the major bulk of primary carbon substrate and co-factors for the biosynthesis of isoprenoid precursors thus shaping the light responses of emissions (Loreto et al., 1996; Niinemets et al., 2002; Rasulov et al., 2009). Light activation of some enzymes in the MEP pathway might further contribute to positive light effects on emissions especially in the longer term control (Rasulov et al., 2009; Rivasseau et al., 2009; Schnitzler et al., 2010). Light dependency is more uncertain for SQT emissions, whose biosynthesis are thought to proceed in the cytosol. Conventional pathway allocation has suggested that the precursors of cytosolic isoprenoids are produced in the mevalonate pathway, with 3-hydroxy3-methylglutaryl-coenzyme-A reductase as the rate limiting enzyme. No light activation of this enzyme has been reported so far (Rodriguez-Concepcion, 2006). However, there is emerging evidence that isoprenoid precursors are exchanged among different compartments, overall from the chloroplasts to the cytosol (Bick and Lange, 2003). Around $80 \%$ of isoprenoid precursors from the MEP pathway can contribute to sesquiterpene biosynthesis (Arimura et al., 2009), which could explain why emissions are light dependent too. Moreover, several studies have been reported that SQT synthesis can also occur in plastids, and vice versa that MT synthesis also occurs in the cytosol. Some terpene synthases 
seem to have dual activities converting different precursors to both SQTs and MTs (e.g. Aharoni et al., 2004; DavidovichRikanati et al., 2008; Sallaud et al., 2009).

The light dependency we could demonstrate for SQT emissions from $Q$. coccifera may also exist in other plant species, which could explain the high slopes $\beta$ of the temperature responses that have been deduced for SQT emissions from outdoor experiments lacking clear separation of temperature and light effects. Indeed in the present study, the mean $\beta$ for SQT emissions was around $0.11 \mathrm{~K}^{-1}$, which is considerably lower than the mean $\beta$ of $0.17 \mathrm{~K}^{-1}$ reported by Ortega et al. (2008).

Based on recent investigations of the metabolic control of isoprene emissions by Rasulov et al. $(2009,2010)$ we hypothesized that at temperatures supraoptimal for photosynthetic processes MT biosynthesis in Q. coccifera leaves could be mostly limited by the availability of isoprenoid precursors produced from photosynthates. Accordingly, we expected that light saturation of MT emissions occurs earlier in the light response at $37^{\circ} \mathrm{C}$ than in the light response at $30^{\circ} \mathrm{C}$, and that $T_{\mathrm{m}}$ occurs earlier in the temperature response at $150 \mu \mathrm{mol} \mathrm{m}^{-2} \mathrm{~s}^{-1}$ PPFD than in the temperature response at $1000 \mu \mathrm{mol} \mathrm{m} \mathrm{m}^{-2} \mathrm{~s}^{-1}$ PPFD. While our results rather confirm the first prediction, they contradict the second one. However, the decrease of the $T_{\mathrm{m}}$ of MT-hc emissions at high assay PPFD was clearly correlated with a decrease in $A_{\mathrm{n}}$ and hence does not conflict with the hypothesis of substratelimited MT biosynthesis at high temperatures. Apparently, high PPFD level accelerated the inhibition of $A_{\mathrm{n}}$ in $Q$. coccifera leaves during temperature ramping, a phenomenon which could also be observed in the light response measured at $37^{\circ} \mathrm{C}$. In the temperature responses, the decline of ETR in the high temperature range was only somewhat delayed with respect to $A_{\mathrm{n}}$ suggesting that electron sinks other than $\mathrm{CO}_{2}$-reduction such as photorespiration became inhibited too. Photorespiration is known to play a pivotal role in maintaining photochemical quenching of the absorbed light energy under conditions $\mathrm{CO}_{2}$-assimilation becomes limited thereby preventing oxidative stress in the chloroplasts (Foyer and Noctor, 2009). In addition, excess light energy can be dissipated non-photochemically as heat. Indeed NPQ significantly increased in the temperature response at low PPFD thus possibly compensated the loss in photochemical quenching under heat stress. By contrast, no significant NPQ increase was seen in the temperature response at high PPFD. In that case, the large excess of light energy that arose at highest temperatures must have led to oxidative stress and damage of PSII as mirrored by the burst of GLVs and persistent inhibition of Fv/Fm. Furthermore, some leaf overheating, not detected by our temperature measurements, may have accentuated stress at high PPFD levels. The dramatic increase of SQT and MT-ox emissions that accompanied the rapid decline of MT-hc emissions in the temperature response at high PPFD may have resulted from enhanced exchanges of isoprenoid precursor between cellular compartments due to sudden increases in membrane permeability (Hüve et al., 2011) together with altered product pattern within specific isoprenoid synthesis routes: thus, a burst of the acyclic MT-ox linalool was observed in plants emitting predominantly the acyclic MT-hc myrcene, while a burst of the cyclic MT-ox $\alpha$-terpineol was observed in plants emitting predominantly the cyclic MT-hc sabinene and eucalyptol. The biosynthesis of acyclic and cyclic MT is known to follow different reaction mechanisms, and within that of the cyclic MT, $\alpha$-terpineol appears to be the direct precursor of eucalyptol (Degenhardt et al., 2009). Finally, the oxidative stress and membrane damages that occurred during heat and high PPFD exposure could have also induced some upregulation of the biosynthesis of SQTs (Loreto and Schnitzler, 2010) and contributed to increase SV emissions from Q. coccifera leaves.

\subsection{Implications for the prediction of BVOC emissions}

Whatever the mechanisms involved, our results showed that interactions between light and temperature responses of MT and SQT emissions can exist as it has been reported for isoprene emissions in some studies (Monson et al., 1992; Tingey et al., 1979, 1987). Above all, light seems to be an important modulator of the temperature optima and high temperature decline of isoprenoid emissions from $Q$. coccifera shaping not only the total quantity but also the quality of the $B V O C$ release. Disregarding this interdependency may engender erroneous estimations of BVOC fluxes during bright hot summer days when temperatures approach $40^{\circ} \mathrm{C}$ (Fig. 4). One may argue that such hot summer days are rare and therefore errors should be small under most circumstances. However, our simulation assumed that leaf temperatures were equal to air temperatures measured above the canopy, because no consistent leaf-to-air temperature differences were detected in our enclosure system during light and temperature ramping. Nevertheless, leaf over-heating may frequently happen in natural conditions (e.g. Singsaas et al., 1999), and be particularly strong in open Mediterranean shrublands during the summer period when plant transpiration is reduced by drought. In the absence of evaporative cooling leaves can easily heat up for $10^{\circ} \mathrm{C}$ above air temperature and reach and exceed values of $40^{\circ} \mathrm{C}$ (Hüve et al., 2011 and references therein). Besides boosting leaf temperatures, drought also reduces $A_{\mathrm{n}}$ and hence intensifies the generation of oxidative stress in leaves (Miller et al., 2010). Thus, stressassociated alterations of emission responses to temperature and light may regularly occur in the Mediterranean already at moderate high air temperatures. Unexpected midday depressions have been observed in situ in the MT emissions from Mediterranean oaks at lower air temperatures than in our simulation (Niinemets et al., 2002; Peñuelas and Llusià, 1999), and exposure to severe drought has shown to disturb or even offset light and temperature responses of isoprenoid emissions (Bertin and Staudt, 1996; Fortunati et al., 2008). 
Understanding the variability of light and temperature responses is also paramount to correctly deduce $E_{\mathrm{S}}$ from field emission data, which otherwise can lead to incorrect estimations of spatial or temporal variations of $E_{\mathrm{S}}$ (Niinemets et al., 2010, 2011). For example in our past investigations of drought effects on MT emissions from Mediterranean oaks, the use of inappropriate responses for the normalization of emission rates to standard conditions may partly explain an apparent discrepancy between the drought resistance of emissions observed in field and greenhouse experiments. In the greenhouse experiments (Bertin and Staudt, 1996; Staudt et al., 2008), plants were exposed only to moderate warm temperatures and incident PPFD, and emissions were measured at standard conditions. By contrast in the field experiments (Lavoir et al., 2009; Staudt et al., 2002), trees were regularly exposed to high temperatures and incident PPFD throughout the period of summer drought, which likely lowered light saturation levels and temperature optima of the emissions response curves. In these studies, emission data, often measured far above standard conditions, were normalized assuming normal response curves of non-stressed plants thus under-estimating $E_{S}$. Consequently in the field experiments $E_{\mathrm{S}}$ appeared to be faster and stronger inhibited by drought than in greenhouse experiments, where no data normalization was performed.

\section{Summary and conclusions}

Our experiments show that MT-hc, ox-MT and SQT emissions, although all found to be light dependent, can exhibit divergent emissions responses that are associated with stress effects occurring at temperatures supraoptimal for photosynthesis. Notably, we could demonstrate that light rapidly and effectively modulates emission responses in the high temperature range entailing large changes in the overall quantity and quality of BVOC release. It is most likely that other environmental factors such as drought, ozone and $\mathrm{CO}_{2}$ concentrations can amplify or attenuate such alterations in the emission responses to temperature and light. We believe that much of the uncertainty in BVOC emission predictions derives from multiple, yet unaccounted interactions among emission drivers that introduce a large amount of variability into BVOC fluxes from terrestrial vegetation. The alterations we observed in the temperature responses of BVOC emissions from $Q$. coccifera were associated with stress and changes in $A_{\mathrm{n}}$ and ETR. Therefore, process-orientated emissions models that link BVOC biosynthesis to photosynthetic processes for non-terpene storing vegetation species should provide a more suitable framework to account for these alterations rather than introducing adjustments in empirical models (Grote et al., 2006; Niinemets et al., 2002; Pacifico et al., 2011). However while true in principle, the reliable prediction of environmental factors on photosynthetic processes and particularly their interactions in stress responses is a task far from being accomplished (e.g. Hüve et al., 2011). Further research to fill our knowledge gaps in these issues is warranted.

Acknowledgements. We thank B. Buatois and A. Rocheteau for their valuable help in BVOC analyses and setting up of the plant exposure system and J.-M. Ourcival for providing the climate data. This study was supported by the projects MIND (EVK2-CT-2002000158), DROUGHT+ (ANR-06-VULN-003-01), the EU IMECC I3 initiative (Infrastructure for Measurements of the European Carbon Cycle 026188) and the French Environmental Agency (ADEME) (project no. 0575C0004).

Edited by: X. Wang

\section{References}

Acacio, V., Holmgren, M., Rego, F., Moreira, F., and Mohren, G. M. J.: Are drought and wildfires turning Mediterranean cork oak forests into persistent shrublands?, Agroforest. Syst., 76, 389400, 2009.

Adams, R. P.: Identification of Essential Oil Components by Gas Chromatography/Mass Spectroscopy, 4th edn, Allured Publishing Corporation, Carol Stream, IL, USA, 2007.

Aharoni, A., Giri, A. P., Verstappen, F. W., Bertea, C. M., Sevenier, R., Sun, Z., Jongsma, M. A., Schwab, W., and Bouwmeester, H. J.: Gain and loss of fruit flavor compounds produced by wild and cultivated strawberry species, Plant Cell, 16, 3110-3131, 2004.

Arimura, G.-I., Matsui, K., and Takabayashi, J.: Chemical and molecular ecology of herbivoreinduced plant volatiles: proximate factors and their ultimate functions, Plant Cell Physiol., 50, 911-923, 2009.

Bellarosa, R., Simeone, M. C., Papini, A., and Schirone, B.: Utility of ITS sequence data for phylogenetic reconstruction of Italian Quercus spp., Mol. Phylogenet. Evol., 34, 355-370, 2005.

Bertin, N. and Staudt, M.: Effect of water stress on monoterpene emissions from young potted holm oak (Quercus ilex L.) trees, Oecologia, 107, 456-462, 1996.

Bick, J. and Lange, B. M.: Metabolic cross talk between cytosolic and plastidial pathways of isoprenoid biosynthesis: unidirectional transport of intermediates across the chloroplast envelope membrane, Arch. Biochem. Biophys., 415, 146-154, 2003.

Bouvier-Brown, N. C., Goldstein, A. H., Gilman, J. B., Kuster, W. C., and de Gouw, J. A.: In-situ ambient quantification of monoterpenes, sesquiterpenes, and related oxygenated compounds during BEARPEX 2007: implications for gas- and particle-phase chemistry, Atmos. Chem. Phys., 9, 5505-5518, doi:10.5194/acp-9-5505-2009, 2009.

Bracho-Nunez, A., Welter, S., Staudt, M., and Kesselmeier, J.: Plant specific volatile organic compound emission rates from young and mature leaves of Mediterranean vegetation, J. Geophys. Res., 116, D16304, doi:10.1029/2010JD015521, 2011.

Ciccioli, P., Brancaleoni, E., Frattoni, M., Di Palo, V., Valentini, R., Tirone, G., Seufert, G., Bertin, N., Hansen, U., Csiky, O., Lenz, R., and Sharma, M.: Emission of reactive terpene compounds from orange orchards and their removal by within-canopy processes, J. Geophys. Res., 104, 8077-8094, 1999.

Copolovici, L., Kännaste, A., Remmel, T., Vislap, V., and Niinemets, Ü.: Volatile emissions from Alnus glutionosa induced 
by herbivory are quantitatively related to the extent of damage, $\mathrm{J}$. Chem. Ecol., 37, 18-28, 2011.

Csiky, O. and Seufert, G.: Terpenoid emissions of Mediterranean oaks and their relation to taxonomy, Ecol. Appl., 9, 1138-1146, 1999.

Davidovich-Rikanati, R., Lewinsohn, E., Bar, E., Iijima, Y., Pichersky, E., and Sitrit, Y.: Overexpression of the lemon basil $\alpha$ zingiberene synthase gene increases both mono- and sesquiterpene contents in tomato fruit, Plant J., 56, 228-238, 2008.

Degenhardt, J., Köllner, T. G., and Gershenzon, J.: Monoterpene and sesquiterpene synthases and the origin of terpene skeletal diversity in plants, Phytochemistry, 70, 1621-1637, 2009.

Demmig-Adams, B. and Adams, W. W.: Photoprotection in an ecological context: the remarkable complexity of thermal energy dissipation, New Phytol., 172, 11-21, 2006.

Duhl, T. R., Helmig, D., and Guenther, A.: Sesquiterpene emissions from vegetation: a review, Biogeosciences, 5, 761-777, doi:10.5194/bg-5-761-2008, 2008.

Fortunati, A., Barta, C., Brilli, F., Centritto, M., Zimmer, I., Schnitzler, J.-P., and Loreto, F.: Isoprene emission is not temperaturedependent during and after severe drought-stress: a physiological and biochemical analysis, Plant J., 44, 687-697, 2008.

Foyer, C. H. and Noctor, G.: Redox regulation in photosynthetic organisms: Signaling, acclimation, and practical implications, Antioxid. Redox Sign., 11, 861-905, 2009.

Geron, C. D. and Arnts, R. R.: Seasonal monoterpene and sesquiterpene emissions from Pinus taeda and Pinus virginiana, Atmos. Environ., 44, 4240-4251, 2010.

Giorgi, F. and Lionello, P.: Climate change projections for the Mediterranean region, Global Planet. Change, 63, 90-104, 2008.

Goldstein, A. H. and Galbally, I. E.: Known and unexplored organic constituents in the earth's atmosphere, Environ. Sci. Technol., 41, 1514-1521, 2007.

Gouinguené, S. P. and Turlings, T. C. J.: The effects of abiotic factors on induced volatile emissions in corn plants, Plant Physiol., 129, 1296-1307, 2002.

Grote, R., Mayrhofer, S., Fischbach, R. J., Steinbrecher, R., Staudt, M., and Schnitzler, J.-P.: Process-based modelling of isoprenoid emissions from evergreen leaves of Quercus ilex L., Atmos. Environ., 40, S152-S165, 2006.

Guenther, A. B., Monson, R. K., and Fall, R.: Isoprene and monoterpene emission rate variability: observations with $\mathrm{Eu}$ calyptus and emission rate algorithm development, J. Geophys. Res., 96, 10799-10808, 1991.

Guenther, A. B., Zimmerman, P. R., Harley, P. C., Monson, R. K., and Fall, R.: Isoprene and monoterpene emission rate variability: model evaluations and sensitivity analyses, J. Geophys. Res., 98, 12609-12617, 1993.

Guenther, A., Karl, T., Harley, P., Wiedinmyer, C., Palmer, P. I., and Geron, C.: Estimates of global terrestrial isoprene emissions using MEGAN (Model of Emissions of Gases and Aerosols from Nature), Atmos. Chem. Phys., 6, 3181-3210, doi:10.5194/acp-63181-2006, 2006.

Haapanala, S., Ekberg, A., Hakola, H., Tarvainen, V., Rinne, J., Hellén, H., and Arneth, A.: Mountain birch - potentially large source of sesquiterpenes into high latitude atmosphere, Biogeosciences, 6, 2709-2718, doi:10.5194/bg-6-2709-2009, 2009.

Hansen, U. and Seufert, G.: The terpenoid emission pattern of Quercus coccifera $\mathrm{L}$. coincides with the emission pattern found with Quercus ilex L., in: The Proceedings of EUROTRAC Symposium 1996, edited by: Borrell, P. M., Borrel, P., Cvitas, T., Kelly, K., and Seiler, W., Computational Mechanics Publications, Southhampton, Garmisch-Partenkirchen, Germany, 2529 March 1996, 235-239, 1996.

Harley, P., Guenther, A., and Zimmerman, P.: Effects of light, temperature and canopy position on net photosynthesis and isoprene emission from sweetgum (Liquidambar styraciflua) leaves, Tree Physiol., 16, 25-32, 1996.

Harley, P., Guenther, A., and Zimmerman, P.: Environmental controls over isoprene emission in deciduous oak canopies, Tree Physiol., 17, 705-714, 1997.

Harley, P., Vasconcellos, P., Vierling, L., Pinheiro, C., Cleomir S., Greenberg, J., Guenther, A., Klinger, L., Almeida, S. S., Neill, D., Baker, T., Phillips, O., and Malhi, Y.: Variation in potential for isoprene emissions among Neotropical forest sites, Glob. Change Biol., 10, 630-650, 2004.

Helmig, D., Ortega, J., Guenther, A., Herrick, J. D., and Geron, C.: Sesquiterpene emissions from loblolly pine and their potential contribution to biogenic aerosol formation in the Southeastern US, Atmos. Environ., 40, 4150-4157, 2006.

Helmig, D., Ortega, J., Duhl, T., Tanner, D., Guenther, A., Harley, P., Wiedinmyer, C., Milford, J., and Sakulyanontvittaya, T.: Sesquiterpene emissions from pine trees - identifications, emission rates and flux estimates for the contiguous United States, Environ. Sci. Technol., 41, 1545-1553, 2007.

Holopainen, J. K. and Gershenzon, J.: Multiple stress factors and the emission of plant VOCs, Trends Plant Sci., 15, 176-184, 2010.

Hüve, K., Bichele, I., Rasulov, B., and Niinemets, Ü.: When it is too hot for photosynthesis: heat-induced instability of photosynthesis in relation to respiratory burst, cell permeability changes and $\mathrm{H}_{2} \mathrm{O}_{2}$ formation, Plant Cell Environ., 34, 113-126, 2011.

Karl, M., Guenther, A., Köble, R., Leip, A., and Seufert, G.: A new European plant-specific emission inventory of biogenic volatile organic compounds for use in atmospheric transport models, Biogeosciences, 6, 1059-1087, doi:10.5194/bg-6-1059-2009, 2009.

Kaye, J. P., Romanya, J., and Vallejo, V. R.: Plant and soil carbon accumulation following fire in Mediterranean woodlands in Spain, Oecologia, 164, 533-543, 2010.

Kesselmeier, J. and Staudt, M.: Biogenic volatile organic compounds (VOC): an overview on emission, physiology and ecology, J. Atmos. Chem., 33, 23-88, 1999.

Kunert, M., Biedermann, A., Koch, T., and Boland, W.: Ultrafast sampling and analysis of plant volatiles by a hand-held miniaturised GC with pre-concentration unit: Kinetic and quantitative aspects of plant volatile production, J. Sep. Sci., 25, 677-684, 2002.

Laothawornkitkul, J., Taylor, J. E., Nigel, P. D., and Hewitt, C. N.: Biogenic volatile organic compounds in the Earth system, New Phytol., 183, 27-51, 2009.

Lavoir, A.-V., Staudt, M., Schnitzler, J. P., Landais, D., Massol, F., Rocheteau, A., Rodriguez, R., Zimmer, I., and Rambal, S.: Drought reduced monoterpene emissions from the evergreen Mediterranean oak Quercus ilex: results from a throughfall displacement experiment, Biogeosciences, 6, 1167-1180, doi:10.5194/bg-6-1167-2009, 2009.

Lerdau, M. T. and Throop, H. L.: Isoprene emission and photosynthesis in a tropical forest canopy: implications for model devel- 
opment, Ecol. Appl., 9, 1109-1117, 1999.

Llusià, J. and Peñuelas, J.: Seasonal patterns of terpene content and emission from seven Mediterranean woody species in field conditions, Am. J. Bot., 87, 133-140, 2000.

Loreto, F. and Schnitzler, J.-P.: Abiotic stresses and induced BVOCs, Trends Plant Sci., 15, 154-166, 2010.

Loreto, F., Ciccioli, P., Cecinato, A., Brancaleoni, E., Frattoni, M., Fabozzi, C., and Tricoli, D.: Evidence of the photosynthetic origin of monoterpenes emitted by Quercus ilex L. leaves by ${ }^{13} \mathrm{C}$ labeling, Plant Physiol., 110, 1317-1322, 1996.

Matsui, K.: Green leaf volatiles: hydroperoxide lyase pathway of oxylipin metabolism, Curr. Opin. Plant Biol., 9, 274-280, 2006.

Maxwell, K. and Johnson, J.: Chlorophyll fluorescence - a practical guide, J. Exp. Bot., 51, 659-668, 2000.

Miller, G., Suzuki, N., Ciftci-Yilmaz, S., and Mittler, R.: Reactive oxygen species homeostasis and signalling during drought and salinity stresses, Plant Cell Environ., 33, 453-467, 2010.

Monson, R. K., Jaeger, C. H., Adams, W. W., Driggers, E. M., Silver, G. M., and Fall, R.: Relationships among isoprene emission rate, photosynthesis, and isoprene synthase activity as influenced by temperature, Plant Physiol., 98, 1175-1180, 1992.

Monson, R. K., Trahan, N., Rosenstiel, T. N., Patrick, V., Moore, D., Wilkinson, M., Norby, R. J., Volder, A., Tjoelker, M. G., Briske, D. D., Karnosky, D. F., and Fall, R.: Isoprene emission from terrestrial ecosystems in response to global change: minding the gap between models and observations, Philos. T. Roy. Soc. A, 365, 1677-1695, 2007.

Niinemets, Ü., Seufert, G., Steinbrecher, R., and Tenhunen, J. D.: A model coupling foliar monoterpene emissions to leaf photosynthetic characteristics in Mediterranean evergreen Quercus species, New Phytol., 153, 257-276, 2002.

Niinemets, Ü., Monson, R. K., Arneth, A., Ciccioli, P., Kesselmeier, J., Kuhn, U., Noe, S. M., Peñuelas, J., and Staudt, M.: The leaflevel emission factor of volatile isoprenoids: caveats, model algorithms, response shapes and scaling, Biogeosciences, 7, 18091832, doi:10.5194/bg-7-1809-2010, 2010.

Niinemets, Ü., Kuhn, U., Harley, P. C., Staudt, M., Arneth, A., Cescatti, A., Ciccioli, P., Copolovici, L., Geron, C., Guenther, A., Kesselmeier, J., Lerdau, M. T., Monson, R. K., and Peñuelas, J.: Estimations of isoprenoid emission capacity from enclosure studies: measurements, data processing, quality and standardized measurement protocols, Biogeosciences, 8, 2209-2246, doi:10.5194/bg-8-2209-2011, 2011.

Olivier, R., Lavoir, A.-V., Ormeño, E., Mouillot, F., Greff, S., Lecareux, C., Staudt, M., and Fernandez, C.: Compost spreading in Mediterranean shrubland indirectly increases biogenic emissions by promoting growth of VOC-emitting plant parts, Atmos. Environ., 45, 3631-3639, doi:10.1016/j.atmosenv.2011.03.060, 2011.

Ormeño, E., Mevy, J. P., Vila, B., Bousquet-Melou, A., Greff, S., Bonin, G., and Fernandez, C.: Water deficit stress induces different monoterpene and sesquiterpene emission changes in Mediterranean species. Relationship between terpene emissions and plant water potential, Chemosphere, 67, 276-284, 2007.

Ormeño, E., Olivier, R., Mévy, J. P., Baldy, V., and Fernandez, C.: Compost may affect volatile and semi-volatile plant emissions through nitrogen supply and chlorophyll fluorescence, Chemosphere, 77, 94-104, 2009.

Ortega, J., Helmig, D., Daly, R. W., Tanner, D. M., Guenther, A.
B., and Herrick, J. D.: Approaches for quantifying reactive and low-volatility biogenic organic compound emissions by vegetation enclosure techniques - Part B: Applications, Chemosphere, 72, 365-380, 2008.

Owen, S. M., Boissard, C., and Hewitt, C. N.: Volatile organic compounds (VOCs) emitted from 40 Mediterranean plant species: VOC speciation and extrapolation to habitat scale, Atmos. Environ., 35, 5393-5409, 2001.

Pacifico, F., Harrison, S. P., Jones, C. D., Arneth, A., Sitch, S., Weedon, G. P., Barkley, M. P., Palmer, P. I., Serça, D., Potosnak, M., Fu, T.-M., Goldstein, A., Bai, J., and Schurgers, G.: Evaluation of a photosynthesis-based biogenic isoprene emission scheme in JULES and simulation of isoprene emissions under present-day climate conditions, Atmos. Chem. Phys., 11, 43714389, doi:10.5194/acp-11-4371-2011, 2011.

Peñuelas, J. and Llusià, J.: Short-term responses of terpene emission rates to experimental changes of PFD in Pinus halepensis and Quercus ilex in summer field conditions, Environ. Exp. Bot., 42, 61-68, 1999.

Peñuelas, J. and Staudt, M.: BVOCs and global change, Trends Plant Sci., 15, 133-144, 2010.

Rasmussen, R. A. and Jones, C. A.: Emission isoprene from leaf discs of Hamamelis, Phytochemistry, 12, 15-19, 1973.

Rasulov, B., Hüve, K., Välbe, M., Laisk, A., and Niinemets, Ü.: Evidence that light, carbon dioxide and oxygen dependencies of leaf isoprene emission are driven by energy status in hybrid aspen, Plant Physiol., 151, 448-460, 2009.

Rasulov, B., Hüve, K., Bichele, I., Laisk, A., and Niinemets, Ü.: Temperature response of isoprene emission in vivo reflects a combined effect of substrate limitations and isoprene synthase activity: a kinetic analysis, Plant Physiol., 154, 1558-1570, 2010.

Rivasseau, C., Seemann, M., Boisson, A. M., Streb, P., Gout, E., Douce, R., Rohmer, M., and Bligny, R.: Accumulation of 2C-methyl-d-erythritol 2,4-cyclodiphosphate in illuminated plant leaves at supraoptimal temperatures reveals a bottleneck of the prokaryotic methylerythritol 4-phosphate pathway of isoprenoid biosynthesis, Plant Cell Environ., 32, 82-92, 2009.

Rodriguez-Concepcion, M.: Early steps in isoprenoid biosynthesis: Multilevel regulation of the supply of common precursors in plant cells, Phytochem. Rev., 5, 1-15, 2006.

Sallaud, C., Rontein, D., Onillon, S., Jabes, F., Duffe, P., Giacalone, C., Thoraval, S., Escoffier, C., Herbette, G., Leonhardt, N., Causse, M., and Tissier, A.: A novel pathway for sesquiterpene biosynthesis from $Z, Z$-Farnesyl pyrophosphate in the wild tomato Solanum habrochaites, Plant Cell, 21, 301-317, 2009.

Schnitzler, J.-P., Louis, S., Behnke, K., and Loivamäki, M.: Poplar volatiles - biosynthesis, regulation and (eco)physiology of isoprene and stress-induced isoprenoids, Plant Biol., 12, 302-316, 2010.

Schuh, G., Heiden, A. C., Hoffmann, T., Kahl, J., Rockel, P., Rudolph, J., and Wildt, J.: Emissions of volatile organic compounds from sunflower and beech: Dependence on temperature and light intensity, J. Atmos. Chem., 27, 291-318, 1997.

Sharkey, T. D., Wiberley, A. E., and Donohue, A. R.: Isoprene Emission from Plants: Why and how, Ann. Bot., 101, 5-18, 2008.

Singsaas, E. L., Laporte, M. M., Shi, J.-Z., Monson, R. K., Bowling, D. R., Johnson, K., Lerdau, M., Jasentuliytana, A., and Sharkey, 
T. D.: Kinetics of leaf temperature fluctuation affect isoprene emission from red oak (Quercus rubra) leaves, Tree Physiol., 19, 917-924, 1999.

Staudt, M. and Lhoutellier, L.: Volatile organic compound emission from holm oak infested by gypsy moth larvae: evidence for distinct responses in damaged and undamaged leaves, Tree Physiol., 27, 1433-1440, 2007.

Staudt, M., Rambal, S., Joffre, R., and Kesselmeier, J.: Impact of drought on seasonal monoterpene emissions from Quercus ilex in southern France, J. Geophys. Res., 107, 4602, doi:10.1029/2001JD002043, 2002.

Staudt, M., Joffre, R., and Rambal, S.: How growth conditions affect the capacity of Quercus ilex leaves to emit monoterpenes, New Phytol., 158, 61-73, 2003.

Staudt, M., Mir, C., Joffre, R., Rambal, S., Bonin, A., Landais, D., and Lumaret, R.: Isoprenoid emissions of Quercus spp. (Q. suber and $Q$. ilex) in mixed stands contrasting in interspecific genetic introgression, New Phytol., 163, 573-584, 2004.

Staudt, M., Ennajah, A., Mouillot, F., and Joffre, R.: Do volatile organic compound emissions of Tunisian cork oak populations originating from contrasting climatic conditions differ in their responses to summer drought?, Can. J. Forest Res., 38, 29652975, 2008.

Staudt, M., Jackson, B., El-Aouni, H., Buatois, B., Lacroze, J.-P., Poessel, J.-L., Sauge, M.-H.: Volatile organic compound emissions induced by the aphid Myzus persicae differ among resistant and susceptible peach cultivars and a wild relative, Tree Physiol., 30, 1320-1334, 2010.
Tarvainen, V., Hakola, H., Hellén, H., Bäck, J., Hari, P., and Kulmala, M.: Temperature and light dependence of the VOC emissions of Scots pine, Atmos. Chem. Phys., 5, 989-998, doi:10.5194/acp-5-989-2005, 2005.

Tingey, D. T., Manning, M., Grothaus, L. C., and Burns, W. F.: The influence of light and temperature on isoprene emission rates from live oak, Physiol. Plantarum, 47, 112-118, 1979.

Tingey D. T., Manning, M., Grothaus, L. C., and Burns, W. F.: Influence of light and temperature on monoterpene emission rates from Slash Pine, Plant Physiol., 65, 797-801, 1980.

Tingey, D. T., Evans, R. C., Bates, E. H., and Gumpertz, M. L.: Isoprene emissions and photosynthesis in three ferns - The influence of light and temperature, Physiol. Plantarum, 69, 609-616, 1987.

Toumi, L. and Lumaret, R.: Genetic variation and evolutionary history of holly oak: a circum-Mediterranean species-complex [Quercus coccifera L./Q. calliprinos (Webb) Holmboe, Fagaceae], Plant Syst. Evol., 290, 159-171, 2010.

Tyson, B. J., Dement, W. A., and Mooney, H. A.: Volatilisation of terpenes from Salvia mellifera, Nature 252, 119-121, 1974.

von Caemmerer, S. and Farquhar, G. D.: Some relationships between the biochemistry of photosynthesis and the gas exchange of leaves, Planta, 153, 376-387, 1981.

Wang, Y.-F., Owen, S. M., Li, Q.-J., and Peñuelas, J.: Monoterpene emissions from rubber trees (Hevea brasiliensis) in a changing landscape and climate: chemical speciation and environmental control, Glob. Change Biol., 13, 2270-2282, 2007. 